\title{
Enhanced insecticide-resistance spectrum in green lacewing predator, Chrysoperla zastrowi sillemi (strain PTS-8) and its potential role in the management of sucking pests of cotton
}

\author{
M. Ashwini ${ }^{1}$, M. Mohan ${ }^{2}$, G. Sivakumar ${ }^{2}$ and T. Venkatesan ${ }^{2, *}$ \\ ${ }^{1}$ Department of Entomology, University of Agricultural Sciences, Gandhi Krishi Vignan Kendra, Bellary Road, Bengaluru 560065 , India \\ ${ }^{2}$ ICAR-National Bureau of Agricultural Insect Resources, Hebbal, Bengaluru 560 024, India
}

The green lacewing or aphid lion, Chrysoperla zastrowi sillemi (Esben-Petersen) is an important predator of sucking pests, and eggs and neonate larvae of lepiodopteran pests under many crop ecosystems of India. In the present study, enhanced insecticide resistance spectrum in an insecticide-resistant population of C. zastrowi sillemi (strain PTS-8) was evaluated against four commonly used insecticides on cotton. The insecticide resistant $C$. zastrowi sillemi PTS-8 showed 16.4-, 14.8-, 12.7- and 7.2-fold resistance against chlorpyriphos $20 \%$ EC, cypermethrin $10 \%$ EC, acetamipirid $20 \%$ SP and chlorantraniliprole $18.5 \%$ SC respectively, compared to the susceptible strain. Biochemical assays revealed an elevated level of three major detoxifying enzymes, viz. carboxylesterase (1.48-fold), glutathione $S$-transferase (1.27-fold) and cytochrome p450 monooxygenase (1.36-fold) in PTS-8 strain compared to the susceptible strain. The field survival and biocontrol potential of PTS-8 strain were significantly better on cotton plants treated with recommended dose of insecticides. The study indicated the potential role of insecticide-resistant natural enemies under biointensive IPM programmes to avoid compatibility conflict with insecticides.

Keywords: Chrysoperla zastrowi sillemi, cotton, detoxifying enzymes, insecticide resistance, sucking pests.

CHRYSOPERLA ZASTROWI SILLEMI (Esben-Petersen; Neuroptera: Chrysopidae), commonly called green lacewing or aphid lion, is a potential predator of insect pests in various crop ecosystems of India ${ }^{1-5}$. Under real field conditions, the predators and parasitoids succumb to a cocktail of insecticides either through direct sprays or by consuming the poisoned prey. In many cases, the sprays are lethal to the predator, which in turn causes pest resurgence and secondary outbreak of minor pests. Nevertheless, natural enemies can develop resistance when they are constantly exposed to insecticides ${ }^{6}$. When the insecticides

*For correspondence. (e-mail: tvenkat12@gmail.com) have become an unavoidable source of pest management, integrating the insecticide-resistant natural enemies with the insecticides will enable us to manage the pests in a sustainable manner with delay in resistance development against insecticides in insect pests.

Among the natural enemies, the populations of green lacewing have revealed a significant level of resistance development against different insecticide ${ }^{7-9}$. Studies were carried out to determine the level of insecticide resistance in different populations of $C$. zastrowi sillemi from India. A pesticide resistant strain of C. zastrowi sillemi (PTS-8) was commercialized which was found highly resistant to endosulfan, acephate and fenvalerate ${ }^{5}$. Synergism studies revealed the enhanced detoxifying enzymes (general esterases, glutathione $S$-transferases and monooxygenases) in the resistant strain of C. zastrowi sillemi ${ }^{5}$.

The scenario of pesticide usage keeps changing with time and it is important to test the enhanced insecticide resistance spectrum of $C$. zastrowi sillemi against new molecules. The augmentative releases of $C$. zastrowi sillemi are usually practised in cotton fields against sucking pests, and eggs and neonate larvae of lepidopteran pests $^{10-12}$. Metabolic enzyme mediated resistance may lead to cross-resistance of different insecticides which have a different mode of action ${ }^{13,14}$. Hence, in the present study we evaluated the enhanced insecticide resistance spectrum in strain PTS-8 of C. zastrowi sillemi against commonly recommended insecticides to determine its compatible use with insecticides under Integrated Pest Management (IPM) programmes.

\section{Materials and methods}

Rearing of C. zastrowi sillemi

Culture of the larval and adult stages of the predator C. zastrowi sillemi was maintained as described by Venkatesan et al. ${ }^{5}$. The susceptible and resistant populations of the predator were continuously maintained in the laboratory. The insecticide-resistant larval population was 
exposed to field-recommended dosage of acephate $(0.67 \mathrm{~g} / 1$ of water $)$ and imidacloprid $(0.4 \mathrm{ml} / 1$ of water $)$ once in three generations.

\section{Insecticides and chemicals}

Based on the recommendations of the Central Insecticide Board Registration Committee, Government of India (www.cibrc.gov.in), chlorpyriphos, cypermethrin, acetamiprid and chlorantraniliprole were selected for studying the enhanced insecticide resistance spectrum in strain PTS- 8 of $C$. zastrowi sillemi and the associated metabolic enzyme assays. Commercial formulations, viz. chlorpyriphos 20\% EC, cypermethrin 10\% EC, acetamiprid 20\% $\mathrm{SP}$ and chlorantraniliprole $18.5 \% \mathrm{SC}$ were used in the study. The other chemicals and reagents used in the enzyme studies were purchased from Sigma-Aldrich Chemical Co, USA.

\section{Dose-response bioassays}

Dose-response bioassays with the insecticides were conducted by taking the field-recommended dosage of each insecticide as the base concentration, and the other concentrations above and below it. The concentrations were further increased in the insecticides, where 50\% mortality was not obtained (Table 1). In each concentration, 100 120 (early second instar) grubs were released on a petri plate and the required concentration of insecticides was sprayed using hand sprayer (0.5 lit. capacity) for 3-5 s. After spraying, the larvae were placed on a tissue paper in order to remove excess insecticides. Such treated larvae were released in a glass vial $(3 \mathrm{~cm} \times 1.5 \mathrm{~cm})$ and provided with UV-treated (to paralyse the embryo and prevent hatching) Corcyra cephalonica eggs. The larvae treated with distilled water were used as control. The larval mortality was recorded 24 and $48 \mathrm{~h}$ after treatment. The moribund larvae were also considered as dead ${ }^{5,15}$.

\section{Preparation of whole-body larval homogenate}

Twenty four-day-old grubs each for resistant and susceptible populations were homogenized thoroughly in $200 \mu \mathrm{l}$

Table 1. Concentrations of insecticides used for bioassay studies

\begin{tabular}{lc}
\hline Insecticide & \multicolumn{1}{c}{ Concentration tested $(\mathrm{ppm})$} \\
\hline Chlorpyriphos 20\% EC & $62.5,125,250,500,1000,2000,4000$ \\
Cypermethrin 10\% EC & $\begin{array}{l}12.5,25,50,100,200,400,800, \\
\end{array}$ \\
Acetamiprid 20\% SP & $5,1000,3,200,6,400,12,800,25,600$ \\
& $2,560,5,120,10,240$ \\
Chlorantraniliprole & $6.87,13.75,27.5,55,110,220,440,880$, \\
$18.5 \%$ SC & $1,760,3,520,7,040,14,080,28,160,56,320$ \\
\hline
\end{tabular}

ice-cold $50 \mathrm{mM}$ phosphate buffer, $\mathrm{pH}$ 6.8. The samples were centrifuged at $12,000 \mathrm{~g}$ for $10 \mathrm{~min}$ at $4^{\circ} \mathrm{C}$. The supernatant was used as the enzyme source. The total protein content of the enzyme sample was determined by Bradford Coomassie Brilliant Blue (CBB) G-250 dye binding method using bovine serum albumin (BSA) as the standard ${ }^{16}$.

\section{Metabolic enzyme assays}

The carboxylesterase activity was determined using $\alpha$ naphthyl acetate as a substrate ${ }^{17}$. The $\alpha$-naphthol formed after the reaction was measured at $595 \mathrm{~nm}$ and quantified using $\alpha$-naphthol standard curve. The qualitative changes in carboxylesterase isozyme profile were determined in resistant and susceptible populations by performing native polyacrylamide gel electrophoresis (PAGE) ${ }^{18}$. To visualize the bands, the gel was stained with freshly prepared staining solution containing $0.05 \% \alpha$-naphthyl acetate and $0.1 \%$ fast blue $B$ salt in $50 \mathrm{mM}$ phosphate buffer, $\mathrm{pH} 6.8$.

The activity of glutathione $S$-transferase was determined spectrophotometrically using 1-chloro-2,4-dinitrobenzene as substrate ${ }^{19}$ and the molar extinction coefficient value of $9.6 \mathrm{mM}^{-1} \mathrm{~cm}^{-1}$. The activity of cytochrome $\mathrm{p} 450$ monooxygenase was determined by $p$-nitroanisole demetylase assay $^{20}$. Molar extinction coefficient $\varepsilon$ value of $p$-nitrophenol $\left(18.2 \mathrm{mM}^{-1} \mathrm{~cm}^{-1}\right)$ was used to calculate enzyme activity and expressed as $\mu \mathrm{mol} / \mathrm{min} / \mathrm{mg}$ of protein.

\section{Survival studies on insecticide resistant C. zastrowi sillmi (strain-PTS-8)}

An experiment was conducted to test the survival of insecticide-resistant C. zastrowi sillemi (PTS-8) under field net-house conditions (insect proof, 100 mesh netting with size of $12 \times 12 \times 15 \mathrm{ft}$ ) during $2017-18$ on the cotton variety DCH-32. Cotton plants (50 days old) were raised on pots under natural conditions and natural infestation of sucking pests. It was found that the plants were naturally infested with the sucking pests, viz. Aphis gossypii, Bemisia tabaci, Thrips tabaci and Phenacoccus solenopsis, and predators, viz. Cheilomenes sexmaculata, Cryptolaemus montrouzieri and ants. Adequate care was taken to remove such natural enemies. The sucking pestsinfested potted cotton plants were transferred to wooden cages individually and placed in the net house. Before release of the predator, the plants were sprayed with different concentrations of insecticides. Four-day-old insecticide-resistant and susceptible $C$. zastrowi sillemi grubs (a) 20 per plant were released on the insecticide sprayed plants after $3 \mathrm{~h}$ of spray. In addition to the sucking pests, adequate quantity of UV-exposed eggs of C. cephalonica were also provided in a card $(4 \times 2 \mathrm{~cm})$ that was stapled on the plants as a feed for the $C$. zastrowi sillemi grubs. 
RESEARCH ARTICLES

Table 2. Relative toxicity of four insecticides to the second instar grubs of resistant (PTS-8) and susceptible populations of Chrysoperla zastrowi sillemi

\begin{tabular}{|c|c|c|c|c|c|c|c|c|}
\hline \multirow[b]{2}{*}{ Insecticide } & \multirow[b]{2}{*}{ Population } & \multirow[b]{2}{*}{$\mathrm{LC}_{50}(\mathrm{ppm})$} & \multicolumn{2}{|c|}{ 95\% Fiducial limit (ppm) } & \multirow[b]{2}{*}{ Slope \pm SE } & \multirow[b]{2}{*}{$\chi^{2}$ value $(\mathrm{d} f)$} & \multirow[b]{2}{*}{$P^{*}$} & \multirow[b]{2}{*}{$\mathrm{RR}^{\#}$} \\
\hline & & & Lower & Upper & & & & \\
\hline \multirow[t]{2}{*}{ Chlorpyriphos $20 \%$ EC } & PTS-8 & $1,172.0$ & 867.87 & $1,679.24$ & $1.53 \pm 0.203$ & $1.568(5)$ & 0.905 & 16.37 \\
\hline & Susceptible & 71.56 & 32.70 & 113.43 & $2.00 \pm 0.229$ & $3.418(5)$ & 0.636 & - \\
\hline \multirow[t]{2}{*}{ Cypermethrin $10 \%$ EC } & PTS-8 & $1,633.92$ & $1,231.02$ & $2,192.13$ & $4.3 \pm 0.134$ & $4.832(10)$ & 0.902 & 14.75 \\
\hline & Susceptible & 110.73 & 78.85 & 151.46 & $2.41 \pm 0.125$ & $3.492(10)$ & 0.967 & - \\
\hline \multirow[t]{2}{*}{ Acetamiprid $20 \% \mathrm{SP}$} & PTS-8 & $1,790.99$ & $1,318.88$ & $2,534.00$ & $4.31 \pm 0.146$ & $5.267(10)$ & 0.920 & 12.74 \\
\hline & Susceptible & 140.40 & 103.39 & 190.20 & $2.72 \pm 0.113$ & $4.543(10)$ & 0.920 & - \\
\hline \multirow[t]{2}{*}{ Chlorantranili prole $18.5 \% \mathrm{SC}$} & PTS-8 & $20,936.12$ & $14,263.21$ & $34,469.68$ & $4.6 \pm 0.145$ & $2.325(12)$ & 0.999 & 7.15 \\
\hline & Susceptible & $2,927.10$ & $2,248.82$ & $3,835.19$ & $4.94 \pm 0.153$ & $5.906(12)$ & 0.921 & - \\
\hline
\end{tabular}

$* P \geq 0.05$ indicates a good fit between observed and expected regression lines in a probit analysis.

S.E. Standard error; $\mathrm{d} f$, Degrees of freedom. ${ }^{\#}$ Resistance ratio $=\mathrm{LC}_{50}$ of resistant PTS-8 population/LC 50 of susceptible population.

Three concentrations of each insecticide were tested against both the populations in three replications along with water-sprayed control. The $\mathrm{LC}_{90}$ dose of each insecticide was taken as a base concentration along with half and double the $\mathrm{LC}_{90}$ doses for both resistant and susceptible populations along with water-sprayed control. Observations on the survival of the grubs were made 1, 3, 5 and 7 days after spraying on the whole plant.

\section{Statistical analysis of data}

The larval mortality data were subjected to Abbott's correction ${ }^{21}$. The corrected data were analysed by probit analysis $^{22}$ to determine the $\mathrm{LC}_{50}$ values using SPSS software version 23 , plotting the probit mortality against log dose in ppm. The resistance ratio against each insecticide was determined by dividing the $\mathrm{LC}_{50}$ values of the resistant population with the susceptible population. The level of resistance for each insecticide was determined based on the classification of resistance given by Kim et al. ${ }^{23}$. Each enzyme assay was performed with three replicates and significant difference of mean enzyme activity in the resistant and susceptible populations was determined based on Student's t-test. Data on survival of larvae in different insecticidal-treated plants were subjected to analysis of variance. Means were compared using Duncan's multiple range test.

\section{Results}

\section{Enhanced insecticide resistance spectrum studies}

The insecticides were screened for their enhanced resistance in laboratory-reared resistant population of C. zastrowi sillemi (strain PTS-8) and susceptible population. Among the four insecticides tested, the highest resistance ratio was recorded for chlorpyriphos (16.4fold), followed by cypermethrin (14.7-fold), acetamiprid (12.7-fold) and the lowest for chlorantraniliprole (7.2fold) in the resistant population compared to the susceptible population (Table 2). Based on the classification of resistance by Kim et al. ${ }^{23}$, the population of C. zastrowi sillemi was moderately resistant to chlorpyriphos, cypermethrin, acetamiprid and showed low resistance to chlorantraniliprole.

\section{Detoxification of insecticides}

All the detoxifying enzymes showed significantly higher levels of activity compared to the susceptible population based on Student's $t$-test (Table 3 ). The resistant population showed 1.48-, 1.27- and 1.36-fold increase in carboxylesterase, glutathione $S$-transferase and cytochrome p450 monooxygenase activity respectively, compared to the susceptible population. The esterase banding pattern of the resistant and susceptible populations revealed the presence of an extra band $\left(E_{1}\right)$ in the resistant population compared to the susceptible population (Figure 1).

\section{Survival of predator under insecticide stressed conditions}

All the insecticides tested showed significant difference in survival of resistant population compared to the laboratory-reared population at different concentrations (Table 4). The number of larvae that survived at 3860 , 7720 and $15,440 \mathrm{ppm}$ of chlorpyriphos at 7 DAS (days after spraying) was $17.67,16.00$ and 8.00 in resistant population and $6.67,5.33$ and 1.33 in susceptible population respectively. For cypermethrin, the concentrations used were $61,101,122,203$ and $244,406 \mathrm{ppm}$, where the larval survival at 7 DAS was $17.33,16.67$ and 8.33 in resistant population and $6.00,4.67$ and 1.67 in susceptible population respectively. At $7360,14,720$ and $29,440 \mathrm{ppm}$ of acetamiprid, the number of larvae that 
Table 3. Metabolic enzyme activities of C. zastrowi sillemi populations

\begin{tabular}{|c|c|c|c|}
\hline $\begin{array}{l}\text { C. zastrowi sillemi } \\
\text { population }\end{array}$ & 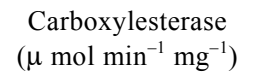 & $\begin{array}{l}\text { Glutathione } S \text {-transferase } \\
\qquad\left(\mu \mathrm{mol} \mathrm{min}{ }^{-1} \mathrm{mg}^{-1}\right)\end{array}$ & $\begin{array}{l}\text { Cytochrome } \mathrm{p} 450 \text { monooxygenase } \\
\qquad\left(\mu \mathrm{mol} \mathrm{min}^{-1} \mathrm{mg}^{-1}\right)\end{array}$ \\
\hline Resistant (PTS-8) & $1.228 \pm 0.012(1.48)$ & $0.084 \pm 0.001(1.27)$ & $0.0168 \pm 0.0001(1.36)$ \\
\hline Susceptible laboratory reared & $0.831 \pm 0.003$ & $0.066 \pm 0.001$ & $0.0123 \pm 0.0001$ \\
\hline
\end{tabular}

The given values of enzyme activity of resistant population differ significantly from susceptible population $(P<0.05)$ based on Student's $t$-test. Values in brackets depict the fold increase activity compared to susceptible population.

\section{Lane 1 Lane 2}

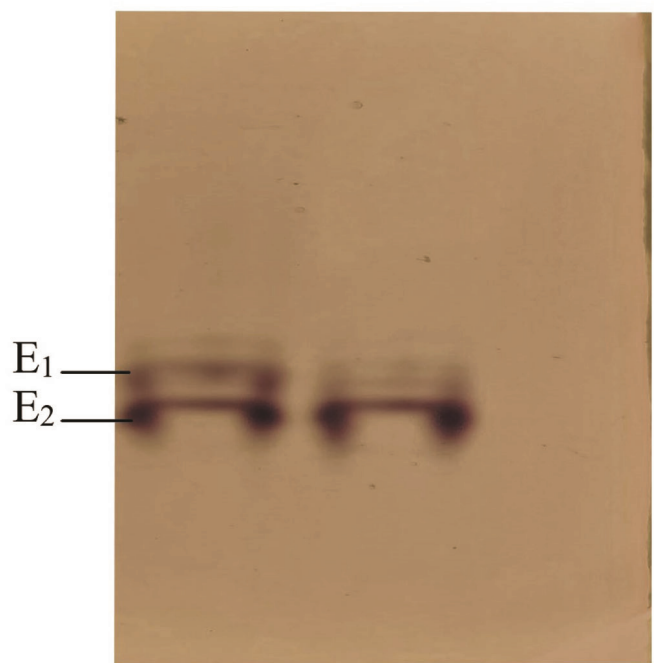

Figure 1. Esterase banding pattern in resistant population. PTS-8 (lane 1) and susceptible population (lane 2) of Chrysoperla zastrowi sillemi (E1, Esterase 1; E2, Esterase 2).

survived at 7 DAS was $17.33,16.00$ and 7.67 in resistant population compared to $6.667,4.667$ and 1.667 in susceptible population respectively. The number of larvae that survived at $123,829,247,659$ and $495,318 \mathrm{ppm}$ of chlorantraniliprole was $17.33,16.33$ and 7.67 in resistant population and $6.00,4.33$ and 2.33 in susceptible population respectively.

The maximum survival of the grubs from the resistant population was recorded at half the concentration of the recommended dosage of all the four insecticides. The larval survival in the recommended dosage of cypermethrin and chlorantraniliprole treatment was on par with half the concentration. At double the concentration of the recommended dosage, the survival was less than 50\%. However, survival of the insecticide-resistant grubs was significantly better than the susceptible ones at all the concentrations of the four insecticides.

\section{Discussion}

The insecticide-induced selection pressure causes development of insecticide resistance in the insects. In the present study, field-collected insecticide-resistant grubs of C. zastrowi sillemi (strain PTS-8) were further sub- jected to selection pressure by exposing them to fieldrecommended dosage of acephate $(0.67 \mathrm{~g} / 1$ of water $)$ and imidacloprid $(0.4 \mathrm{ml} / 1$ of water) once in three generations under laboratory conditions. Such a resistant predator was exposed to new insecticides, viz. chlorpyriphos, cypermethrin, acetamiprid and chlorantraniliprole. The strain PTS-8, originally collected from Sri Ganganagar, Rajasthan, showed 50.4-, 66.1- and 277.5-fold resistance for endosulfan, fenvalerate and acephate respectively ${ }^{5}$, and strain also showed resistance to new insecticides. Similar studies from Pakistan reported 53-160-fold resistance to chlorpyriphos and 1-8-fold resistance to deltamethrin in 15 field populations of Chrysoperla carnea ${ }^{15}$. In the adults of $C$. carnea, Sohail et al. ${ }^{24}$ reported 15 -fold resistance to acetamiprid.

Metabolic enzymes are responsible for the detoxification of insecticidal molecules in insects. Esterases, glutathione $S$-transferases and cytochrome p450 monooxygenases are the most common metabolic enzymes involved in insecticide resistance $e^{5,15,25,26}$. All the three enzymes showed significantly elevated levels of activity in the resistant population compared to the susceptible population. These metabolic enzymes are known to act together, but only the proportion of enzyme activity varies with insecticides. Synergism studies conducted previously also revealed the role of these three enzymes in insecticide resistance in the same population of C. zastrowi sillemi ${ }^{5}$. The role of esterase as the major factor of resistance to synthetic pyrethroids in $C$. carnea was reported in previous studies ${ }^{25,27}$. Association of esterases and monooxygenases with organophosphate and pyrethroid resistance in C. carnea field populations in Canada has been reported ${ }^{7}$. The esterase banding pattern also confirmed the difference in esterase activity of resistant and susceptible populations. The difference in esterase activity can be depicted by variation in the number of bands and thickness of the bands ${ }^{28}$. The extra band in the resistant population could be due to induction of additional esterases responsible for hydrolysis of the insecticidal molecule.

Cross-resistance denotes that resistance to one insecticide in insects confers resistance to another insecticide, even when the insect is not exposed to it earlier. Crossresistance is known to exist between insecticides having similar binding target sites or similar detoxifying pathways $^{29}$. Metabolic enzyme-mediated resistance could confer cross-resistance to a different group of insecticides ${ }^{14}$. 
RESEARCH ARTICLES

Table 4. Survival of insecticide-resistant (PTS-8) and susceptible populations of C. zastrowi sillemi on insecticide-treated cotton plants

\begin{tabular}{|c|c|c|c|c|c|c|c|c|c|}
\hline \multicolumn{5}{|c|}{ Chlorpyriphos } & \multicolumn{5}{|c|}{ Cypermethrin } \\
\hline $\begin{array}{l}\text { Treatment (dosage (ppm) } \\
\text { and (strain) }\end{array}$ & $1 \mathrm{DAS}$ & 3 DAS & 5 DAS & 7 DAS & $\begin{array}{l}\text { Treatment (dosage (ppm) } \\
\text { and strain) }\end{array}$ & $1 \mathrm{DAS}$ & 3 DAS & 5 DAS & 7 DAS \\
\hline 3860 (PTS-8) & $19.33^{\mathrm{a}}$ & $19.00^{\mathrm{ab}}$ & $18.33^{\mathrm{ab}}$ & $17.67^{\mathrm{b}}$ & 61101 (PTS-8) & $19.000^{\mathrm{a}}$ & $18.667^{\mathrm{a}}$ & $18.000^{\mathrm{a}}$ & $17.333^{\mathrm{ab}}$ \\
\hline 3860 (susceptible) & $13.00^{\mathrm{b}}$ & $10.67^{\mathrm{c}}$ & $8.00^{\mathrm{c}}$ & $6.67^{\mathrm{e}}$ & 61101 (susceptible) & $11.000^{\mathrm{b}}$ & $10.667^{\mathrm{b}}$ & $8.333^{\mathrm{bc}}$ & $6.000^{\mathrm{d}}$ \\
\hline 7720 (PTS-8) & $18.33^{\mathrm{a}}$ & $18.00^{\mathrm{b}}$ & $17.33^{b}$ & $16.00^{\mathrm{c}}$ & 122203 (PTS-8) & $19.333^{\mathrm{a}}$ & $19.000^{\mathrm{a}}$ & $18.667^{\mathrm{a}}$ & $16.667^{\mathrm{b}}$ \\
\hline 7720 (susceptible) & $9.66^{\mathrm{c}}$ & $9.00^{\mathrm{d}}$ & $7.33^{\mathrm{c}}$ & $5.33^{\mathrm{f}}$ & 122203 (susceptible) & $8.667^{\mathrm{c}}$ & $8.333^{\mathrm{c}}$ & $7.000^{\mathrm{c}}$ & $4.667^{\mathrm{d}}$ \\
\hline 15440 (PTS-8) & $12.00^{\mathrm{b}}$ & $10.67^{\mathrm{c}}$ & $8.67^{\mathrm{c}}$ & $8.00^{\mathrm{d}}$ & 244406 (PTS-8) & $11.000^{\mathrm{b}}$ & $10.000^{\mathrm{b}}$ & $9.000^{\mathrm{b}}$ & $8.333^{\mathrm{c}}$ \\
\hline 15440 (susceptible) & $5.00^{\mathrm{d}}$ & $4.00^{\mathrm{e}}$ & $2.33^{\mathrm{d}}$ & $1.33^{\mathrm{g}}$ & 244406 (susceptible) & $5.333^{\mathrm{d}}$ & $4.333^{\mathrm{d}}$ & $3.333^{\mathrm{d}}$ & $1.667^{\mathrm{e}}$ \\
\hline Untreated control & $19.66^{\mathrm{a}}$ & $19.67^{\mathrm{a}}$ & $19.33^{\mathrm{a}}$ & $19.00^{\mathrm{a}}$ & Untreated control & $19.667^{\mathrm{a}}$ & $19.667^{\mathrm{a}}$ & $19.333^{\mathrm{a}}$ & $19.000^{\mathrm{a}}$ \\
\hline $\operatorname{S.Em}( \pm)$ & 0.549 & 0.488 & 0.535 & 0.398 & S.Em $( \pm)$ & 0.504 & 0.418 & 0.549 & 0.563 \\
\hline SED & 0.777 & 0.690 & 0.755 & 0.563 & SED & 0.713 & 0.591 & 0.777 & 0.797 \\
\hline CD@5\% & 1.667 & 1.480 & 1.621 & 1.209 & CD@5\% & 1.529 & 1.267 & 1.666 & 1.709 \\
\hline \multicolumn{5}{|c|}{ Acetamiprid } & \multicolumn{5}{|c|}{ Chlorantraniliprole. } \\
\hline $\begin{array}{l}\text { Treatment (dosage (ppm) } \\
\text { and strain) }\end{array}$ & 1 DAS & 3 DAS & 5 DAS & 7 DAS & $\begin{array}{l}\text { Treatment (dosage (ppm) } \\
\text { and strain) }\end{array}$ & 1 DAS & 3 DAS & 5 DAS & 7 DAS \\
\hline 7360 (PTS-8) & $18.667^{\mathrm{a}}$ & $17.667^{b}$ & $17.667^{\mathrm{b}}$ & $17.333^{\mathrm{b}}$ & 123829 (PTS-8) & $19.667^{\mathrm{a}}$ & $19.333^{\mathrm{a}}$ & $18.333^{\mathrm{ab}}$ & $17.333^{b}$ \\
\hline 7360 (susceptible) & $9.000^{\mathrm{cd}}$ & $8.333^{c}$ & $7.667^{\mathrm{de}}$ & $6.667^{\mathrm{e}}$ & 123829 (susceptible) & $8.333^{\mathrm{c}}$ & $8.000^{\mathrm{d}}$ & $7.000^{\mathrm{d}}$ & $6.000^{\mathrm{d}}$ \\
\hline 14720 (PTS-8) & $17.000^{\mathrm{b}}$ & $16.667^{\mathrm{b}}$ & $16.333^{c}$ & $16.000^{\mathrm{c}}$ & 247659 (PTS-8) & $18.333^{\mathrm{a}}$ & $17.667^{\mathrm{b}}$ & $17.000^{\mathrm{b}}$ & $16.333^{\mathrm{b}}$ \\
\hline 14720 (susceptible) & $8.000^{\mathrm{d}}$ & $7.667^{\mathrm{c}}$ & $6.667^{\mathrm{e}}$ & $4.667^{f}$ & 247659 (susceptible) & $7.333^{\mathrm{c}}$ & $6.667^{\mathrm{e}}$ & $6.000^{\mathrm{d}}$ & $4.333^{\mathrm{e}}$ \\
\hline 29440 (PTS-8) & $9.667^{\mathrm{c}}$ & $8.333^{c}$ & $8.000^{\mathrm{d}}$ & $1.667^{\mathrm{g}}$ & 495318 (PTS-8) & $13.000^{\mathrm{b}}$ & $10.667^{\mathrm{c}}$ & $8.667^{\mathrm{c}}$ & $7.667^{\mathrm{c}}$ \\
\hline 29440 (susceptible) & $4.667^{\mathrm{e}}$ & $4.000^{\mathrm{d}}$ & $2.667^{f}$ & $1.667^{\mathrm{g}}$ & 495318 (susceptible) & $5.333^{\mathrm{d}}$ & $4.667^{\mathrm{f}}$ & $3.333^{\mathrm{e}}$ & $2.333^{\mathrm{f}}$ \\
\hline Untreated control & $19.667^{\mathrm{a}}$ & $19.667^{\mathrm{a}}$ & $19.333^{\mathrm{a}}$ & $19.000^{\mathrm{a}}$ & Untreated control & $19.667^{\mathrm{a}}$ & $19.667^{\mathrm{a}}$ & $19.333^{\mathrm{a}}$ & $19.000^{\mathrm{a}}$ \\
\hline $\operatorname{S.Em}( \pm)$ & 0.333 & 0.436 & 0.378 & 0.282 & S.Em $( \pm)$ & 0.577 & 0.436 & 0.454 & 0.418 \\
\hline SED & 0.471 & 0.617 & 0.535 & 0.398 & SED & 0.817 & 0.617 & 0.642 & 0.591 \\
\hline CD@5\% & 1.011 & 1.323 & 1.146 & 0.855 & CD@5\% & 1.751 & 1.323 & 1.378 & 1.267 \\
\hline
\end{tabular}

DAS, Days after spraying. Means followed by the same alphabet do not differ significantly by DMRT $(P=0.05 \%)$.

Overexpression of non-specific enzymes such as monooxygenases results in resistance to a broad spectrum of insecticides ${ }^{9,30}$. The elevated levels of enzyme activity in the resistant population (PTS-8) confirmed the metabolic detoxification of insecticides, and it was evident that the population showed cross-resistance to different insecticides tested.

Field trials under netted conditions revealed significant variability in the survival of resistant population than the susceptible population at different concentrations. The survival of resistant population ranged from $88.4 \%$ to $86.7 \%$ for half the recommended dose of all the chemicals, $80 \%$ to $83 \%$ for the recommended dosage and $33.3 \%$ to $30 \%$ for double the recommended dosage of the insecticides. It was also found that the larvae were able to reach pupal stage at $7 \mathrm{DAS}$, mostly in the resistant population (PTS-8). Among the pests, P. solenopsis and B. tabaci were able to survive on the insecticide-sprayed plants which were the feeding source for the chrysopid predators. This reveals the profound ability of strain PTS8 to resist high doses of insecticides even under field conditions. Studies on insecticide resistance have proved the resistance of Chrysoperla towards organophospates, synthetic pyrethroids and neonicotinoides ${ }^{5,9,15}$. It is noteworthy that the strain of predator which would tolerate high doses of insecticides sustains better when integrated under IPM programmes and keeps a check on the pest population regularly.

\section{Conclusion}

The present study confirms enhanced insecticide resistance spectrum among organophosphates, synthetic pyrethroids and neonicotinoids in the resistant strain PTS-8 of C. zastrowi sillemi. Its field survival at the recommended doses of insecticides indicates the compatibility of biological control and chemicals. Currently, the strain PTS-8 has been commercialized to industrial partners for largescale multiplication and release. The release of insecticide-resistant predator also has the potential to slow down the rate of evolution of insecticide resistance in pest species and resurgence of sucking pests.

1. Dhandapani, N., Pallavi, S. and Mishra, G., Chrysopids. In Ecofriendly Pest Management for Food Security (ed. Omkar), Elsevier, San Diego, USA, 2016, pp. 311-327.

2. Henry, C. S., Brooks, S. J., Johnson, J. B., Venkatesan, T. and Duelli, P., The most important lacewing species in Indian agricultural crops, Chrysoperla sillemi (Esben-Petersen), is a subspecies of Chrysoperla zastrowi (Esben-Petersen) (Neuroptera: Chrysopidae). J. Nat. Hist., 2010, 44, 2543-2555; https://doi.org/ 10.1080/00222933.2010.499577.

3. Pappas, M. L., Broufas, G. D. and Koveos, D. S., Chrysopid predators and their role in biological control. J. Entomol., 2011, 8(3), 301-326; https://doi.org/10.3923/je.2011.301.326.

4. Senior, L. J. and McEwen, P. K., The use of lacewings in biological control. In Lacewings in the Crop Environment (eds McEwen, P. K., New, T. R. and Whittington, A. E.), Cambridge University Press, Cambridge, UK, 2011, pp. 296-299. 


\section{RESEARCH ARTICLES}

5. Venkatesan, T., Mahiba, S. H., Jalali, S., Ramya, S. and Pratibha, M., Detection of insecticide resistance and mechanisms of resistance in field populations of Chrysoperla zastrowi sillemi (Neuroptera: Chrysopidae) collected from different geographical locations in India. J. Biol. Control, 2017, 31(3), 61-68; https:// doi.org/10.18311/jbc/2017/16333.

6. Roush, R. T. and Daly. J. C., The role of population genetics in resistance research and management. In Pesticide Resistance in Arthropods (eds Roush, R. T. and Tabashnik B. E.), Springer, USA, 1990, pp. 97-152.

7. Pree, D. J., Archibald, D. E. and Morrison, R. K., Resistance to insecticides in the common green lacewing Chrysoperla carnea (Neuroptera: Chrysopidae) in southern Ontario. J. Econ. Entomol., 1989, 82(1), 29-34; https://doi.org/10.1093/jee/82.1.29.

8. Daane, K. M., Ecological studies of released lacewings in crops. In Lacewings in the Crop Environment (eds McEwen, P. K., New, T. R. and Whittington, A. E.), Cambridge University Press, Cambridge, UK, 2001, pp. 338-345.

9. Mansoor, M. M. and Shad, S. A., Genetics, cross-resistance and realized heritability of resistance to acetamiprid in generalist predator, Chrysoperla carnea (Steph.) (Neuroptera: Chrysopidae). Egypt. J. Biol. Pest Control, 2020, 30, 23; https://doi.org/10.1186/ s41938-020-0213-x.

10. Easterbrooka, M. A., Fitzgeralda, J. D. and Solomona, M. G., Suppression of aphids on strawberry by augmentative releases of larvae of the lacewing Chrysoperla carnea (Stephens), Biocontrol Sci. Technol., 2006, 16(9), 893-900; https://doi.org/10.1080/ 09583150600827850 .

11. Venkatesan, T., Singh, S. P. and Jalali, S. K., Rearing of Chrysoperla carnea (Neuroptera: Chrysopidae) on semi-synthetic diet and its predatory efficiency against cotton pests. Entomon, 2000, 25(2), 81-89.

12. Venkatesan, T., Singh, S. P., Jalali, S. K. and Joshi, S., Evaluation of predatory efficiency of Chrysoperla carnea (Stephens) reared on artificial diet against tobacco aphid Myzus persicae (Sultzer) in comparison with other predators. J. Entomol. Res., 2002, 26(3), 193-196.

13. Panini, M., Manicardi, G. C., Moores, G. D. and Mazzoni, E., An overview of the main pathways of metabolic resistance in insects. Invertebr. Surviv. J., 2016, 13(1), 326-335; https://doi.org/ 10.25431/1824-307X/isj.v13i1.326-335.

14. Oakeshott, J. G., Claudianos, C., Campbell, P. M., Newcomb, R. D. and Russell, J. R., Biochemical genetics and genomics of insect esterases. In Comprehensive Molecular Insect Science (eds Gilbert, L. I., Iatro, K. and Gill, S.), Elsevier, The Netherlands, 2010, pp. 1-73.

15. Pathan, A. K., Sayyed, A. H., Aslam, M., Razaq, M., Jilani, G. and Saleem, M. A. Evidence of field-evolved resistance to organophosphates and pyrethroids in Chrysoperla carnea (Neuroptera: Chrysopidae). J. Econ. Entomol., 2008, 101(5), 1676-1684; https://doi.org/10.1093/jee/101.5.1676.

16. Bradford, M. M., A rapid and sensitive method for the quantification of microgram quantities of protein utilizing the principle of protein-dye binding. Anal. Biochem., 1976, 74, 248-254; https://doi.org/10.1016/0003-2697(76)90527-3.

17. Van Asperen, K., A study of housefly esterases by means of a sensitive colorimetric method. J. Insect Physiol., 1962, 8, 401-416; https://doi.org/10.1016/0022-1910(62)90074-4.

18. Davis, B. J., Disc electrophoresis II. Method and application to human serum proteins. Ann. NY Acad. Sci., 1964, 121, 404-427; https://doi.org/10.1111/j.1749-6632.1964.tb14213.x.
19. Kao, C. H., Hung, C. F. and Sun, C. N., Parathion and methyl parathion resistance in diamondback moth (Lepidoptera: Plutellidae) larvae. J. Econ. Entomol., 1989, 82(5), 1299-1304; https:// doi.org/10.1093/jee/82.5.1299.

20. Kinoshita, F. K., Frawley, J. P. and Du Bois, K. P., Quantitative measurement of induction of hepatic microsomal enzymes by various dietary levels of DDT and toxaphene in rats. Toxicol. Appl. Pharmacol., 1966, 9, 505-511; https://doi.org/10.1016/0041008X(66)90011-1.

21. Abbott, W. S., A method of computing the effectiveness of an insecticide. J. Econ. Entomol., 1925, 18(2), 265-267; https://doi.org/ 10.1093/jee/18.2.265a.

22. Finney, D. J., Probit Analysis: A Statistical Treatment of the Sigmoid Response Curve, Cambridge University Press, Cambridge, UK, 1952, p. 318.

23. Kim, Y. J., Lee, H. S., Lee, S. W., Kim, G. H. and Ahn, Y. J., Toxicity of tebufenpyrad to Tetranychus urticae (Acari: Tetranychidae) and Amblyseius womersleyi (Acari: Phytoseiidae) under laboratory and field conditions. J. Econ. Entomol., 1999, 92(1), 187-192; https://doi.org/10.1093/jee/92.1.187.

24. Sohail, M., Nasar, M. H., Muhammad, R., Soomro, Q. A., Asif, M. U. and Maari, J. M., Resistance potential of Chrysoperla carnea (Stephens) to insecticides used against sucking complex of cotton. Int. J. Ecotoxicol. Ecobiol., 2019, 4(1), 1-7; https:// doi.org/10.11648/J.IJEE.20190401.11.

25. Ishaaya, I., Insect detoxifying enzymes: their importance in pesticide synergism and resistance. Arch. Insect Biochem. Physiol., 1993, 22(1-2), 263-276; https://doi.org/10.1002/arch.940220119.

26. Mohan, M. and Gujar, G. T., Local variation in susceptibility of the diamondback moth, Plutella xylostella (Linnaeus) to insecticides and role of detoxification enzymes. Crop Prot., 2003, 22(3), 495-504; https://doi.org/10.1016/S0261-2194(02)00201-6.

27. Grafton-Cardwell, E. E. and Hoy, M. A., Genetic improvement of common green lacewing, Chrysoperla carnea (Neuroptera: Chrysopidae): selection for carbaryl resistance. Environ. Entomol., 1986, 15(6), 1130-1136; https://doi.org/10.1093/ee/15.6.1130.

28. Mehrab, C., Mohammad, S. A., Breza, M. S., Browshan, A. B. and Banwara, B., Esterase banding pattern in different developmental stages of Culex quinquefasciatus Say 1823 (Diptera: Culicidae). Int. J. Adv. Biol. Res., 2016, 6(4), 553-557.

29. Wu, Y., Detection and mechanisms of resistance evolved in insects to Cry toxins from Bacillus thuringiensis. Adv. Insect Physiol., 2014, 47, 297-342; https://doi.org/10.1016/B978-0-12800197-4.00006-3.

30. Luo, C., Jones, C., Devine, G., Zhang, F., Denholm, I. and Gorman, K., Insecticide resistance in Bemisia tabaci biotype Q (Hemiptera: Aleyrodidae) from China. Crop Protect., 2010, 29, 429-434; https://doi.org/10.1016/j.cropro.2009.10.001.

ACKNOWLEDGEMENT. We thank the Director, ICAR-NBAIR, Bengaluru, for providing the necessary infrastructure facilities to carry out the work.

Received 22 September 2020; accepted 4 November 2020

doi: $10.18520 / \mathrm{cs} / \mathrm{v} 120 / \mathrm{i} 2 / 423-428$ 